\title{
Penyuluhan Pemberdayaan Masyarakat Desa Dalam Meningkatkan Perekonomian Keluarga
}

\author{
${ }^{1}$ Ahmad Zakaria, ${ }^{2}$ Mhd Adlin, ${ }^{3}$ Rino Agung Fambudi, ${ }^{4}$ Indri Lutfitriyani, ${ }^{5}$ Ristyana Fitrani \\ Sukma Pratiwi, ${ }^{*}$ Denok Sunarsi \\ Universitas Pamulang, Tangerang Selatan, Banten, Indonesia \\ *denoksunarsi@unpam.ac.id
}

\begin{abstract}
Abstrak
Tujuan Pengabdian Kepada Masyarakat (PKM) Mahasiswa ini adalah untuk memberikan pengetahuan dan pemahaman kepada elemen Masyaraka untuk meningkatkan peran serta masyarakat dalam mewujudkan kesejahteraan ekonomi di desa cidokom, kecamatan gunung sindur, Kabupaten bogor, jawa barat. Melalui upaya ini diharapkan keluarga-keluarga yang masih tergolong Pra sejahtera dan sejahtera mampu berusaha dalam rangka meningkatkan ekonomi dan pendapatan kelurga. Kegiatan pemberdayaan ekonomi keluarga ini juga dapat meningkatkan akses pada berbagai sumber daya yang dibutuhkan agar dapat meningkatkan kualitas usahanya, antara lain dalam pengembangan modal produksi pemasaran dan peningatkan ketrampilan.
\end{abstract}

Kata Kunci: Pemberdayaan Masyarakat, Meningkatkan Perekonomian.

\section{Abstract}

The purpose of this Student Community Service (PKM) is to provide knowledge and understanding to elements of society to increase community participation in realizing economic prosperity in Cidokom Village, Gunung Sindur District, Bogor Regency, West Java. Through this effort, it is hoped that families who are still classified as pre-prosperous and prosperous are able to work in order to improve the economy and family income. This family economic empowerment activity can also increase access to various resources needed in order to improve the quality of its business, including in developing production capital, marketing and improving skills.

Keywords: community empowerment, improve the economy.

\section{PENDAHULUAN}

Manajemen merupakan salah satu program studi di Universitas Pamulang. Program studi ini memiliki andil dalam mencetak lulusan yang berkarakter serta mampu bersaing di dalam dunia kerja, serta dapat berperan bagi pembangunan. Pengabdian kepada masyarakat adalah bentuk Kegiatan pengabdian kepada masyarakat yang merupakan salah satu Tri Dharma Perguruan Tinggi Selain Pendidikan dan Penelitian, sesuai Undang-Undang RI Nomor 20 Tahun 2003 tentang Sistem Pendidikan Nasional, pada Pasal 20 ayat 2. Pengabdian kepada masyarakat adalah suatu kegiatan yang bertujuan membantu masyarakat tertentu dalam beberapa aktivitas tanpa mengharapkan imbalan dalam bentuk apapun. Secara umum program ini dirancang oleh berbagai universitas atau institute yang ada di Indonesia begitu pula di Universitas Pamulang (UNPAM) untuk memberikan kontribusi nyata bagi bangsa Indonesia. Khususnya dalam pengembangan diri bagi pemuda karang taruna desa cidokom.

Fenomena yang terjadi dijaman sekarang adalah susahnya mencari lapangan pekerjaan dan penghasilan tambahan, maka dari itu dengan progam mengenai pengembangan diri melalui pelatihan dalam menghadapi pandemic covid-19 dengan tema "Penyuluhan Pemberdayaan Masyarakat Desa Dalam Meningkatkan Perekonomian Keluarga” akan meningkatkan kualitas ekonomi masyarakat.

Pemberdayaan masyarakat merupakan suatu rangkaian tindakan yang sistematis dan melibatkan berbagai komponen organisasi formal dan non formal. Pemberdayaan masyarakat adalah suatu gerakan (movement) untuk menghimpun kekuatan dan kemampuan masyarakat beserta lingkungannya. 
Selanjutnya Prasojo, (2004) juga menyatakan bahwa strategi pemberdayaan masyarakat tidak dapat diimplementasikan jika tidak sertai dengan sejumlah sumber-sumber kewenangan, manajemen, program dan pembiayaan. Dalam kaitan tersebut, Pemberdayaan masyarakat harus didasari pada asumsi, bahwa masyarakat adalah pemilik kewenangan sekaligus aktor yang menentukan kebutuhan dan strategi untuk mencapai kebutuhan tersebut. Pemerintah hanya bertindak sebagai fasilitator dan regulator. Semua proses perencanaan, pelaksanaan dan pengawasan pada dasarnya harus dilakukan sendiri oleh masyarakat melalui lembaga-lembaga yang memiliki otoritas.

Pemberdayaan masyarakat desa merupakan salah satu upaya untuk meningkatkan kesejahteraan masyarakat, melalui beberapa kegiatan antara lain peningkatan prakarsa dan swadaya masyarakat, perbaikan lingkungan dan perumahan, pengembangan usaha ekonomi desa, pengembangan Lembaga Keuangan Desa, serta kegiatan-kegiatan yang dapat meningkatkan kemampuan masyarakat dalam menaikkan hasil produksinya.

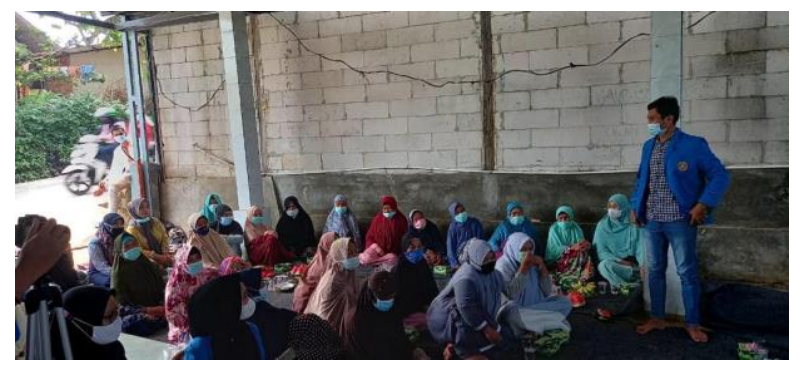

Gambar. 1 Untuk melaksanakan tugasnya dalam pemberdayaan masyarakat desa, para pekerja atau fasilitator harus profesional, memiliki kemampuan dan keterampilan terkait. Setiap unsur harus kompeten, mempunyai kemampuan dalam memahami teori dan bertindak praktis, serta dapat membuat refleksi

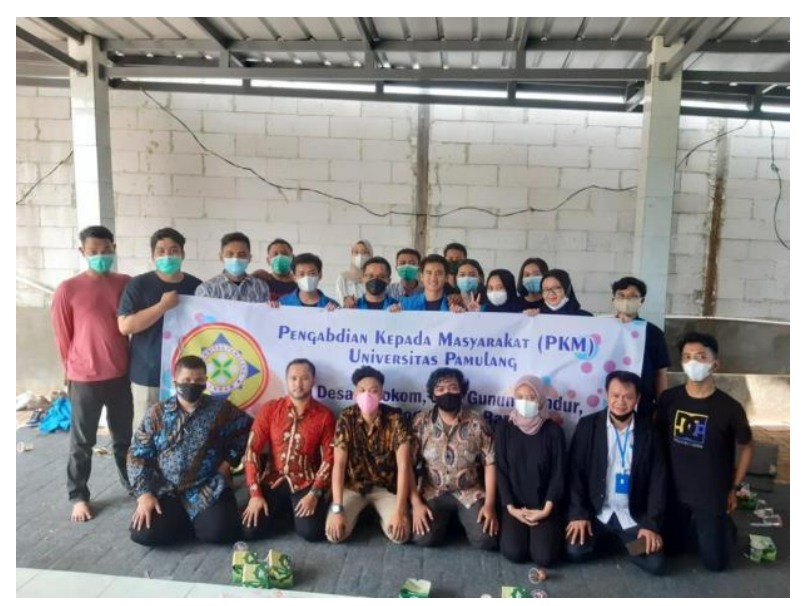

Gambar. 2 Adapun program yang dilakukan dalam rangka meningkatkan kesejahteraan masyarakat sebagai bentuk nyata pemberdayaan yang dilakukan selama ini seperti pembinaan dan pelatihan perkoperasian namun semuanya ini belum berjalan secara optimal.

\section{METODE PELAKSANAAN}

Dengan menggunakan diskusi kelompok penyuluhan ini di harapkan untuk meningkatkan perekonomian keluarga, Metode kegiatan ini adalah mendatangi Mushola dan para ibu-ibu desa tersebut dan memberikan sedikit wawasan dan diskusi untuk berusaha dalam rangka meningkatkan ekonomi dan pendapatan kelurga.

\section{HASIL DAN PEMBAHASAN}

Hasil penelitian dan pembahasan dalam penelitian ini diuraikan berdasarkan indikator yang digunakan yakni 1) tingkat pembinaan kelompok usaha ekonomi masyarakat; 2) tingkat 
Ketrampilan menjahit; 3) tingkat penyuluhan memelihara ternak; 4) tingkat pemanfaatan teknologi tepat guna; dan 5) tingkat pengolahan pekarangan.

\section{Tingkat Pembinaan Kelompok Usaha Ekonomi Masyarakat}

Data dan informasi tentang tingkat pembinaan kelompok usaha ekonomi masyarakat diperoleh dengan cara melakukan wawancara

Dalam rangka pengembangan usaha ekonomi keluarga seperti usaha dagang (kios), maka mahasiswa memberikan pendampingan kepada masyarakat yang melakukan usaha ekonomi seperti kios dalam memberikan kesejahteraan bagi kehidupan masyarakatnya

\section{Tingkat Ketrampilan Menjahit}

Memberikan pelatihan dan kursus menjahit kepada masyarakat terutama melalui program kesejahteraan keluarga (PKK). Tujuannya adalah agar masyarakat paling tidak memiliki ketrampilan menjahit terutama untuk komsumsi pribadi dalam keluarga. Walaupun selama ini tidak berjalan secara optimal karena masyarakat kami rata-rata bekerja sebagai petani sehingga lebih banyak fokusnya pada bidang pengolahan lahan perkebunan, tetapi ada peningkatan ketrampilan menjahit yang diberikan walaupun belum berjalan secara optimal.

\section{Tingkat Penyuluhan Memelihara Ternak}

Penyuluhan tentang cara beternak yang baik dan manfaat ternak bagi kehidupan masyarakat desa yakni dalam rangka membiayai anaknya yang sedang sekolah atau keluarga yang menjadi tanggungannya yang sedang melanjutkan pendidikan,,

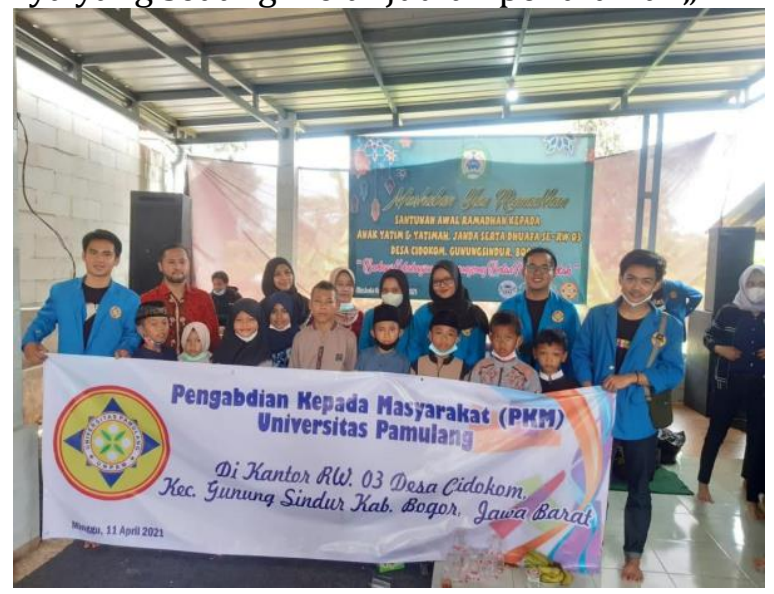

Gambar. 3

\section{Tingkat Pemanfaatan Teknologi Tepat Guna}

Menjelaskan bahwa pemberdayaan masyarakat terkait erat dengan keberdayaan masyarakat, yaitu kemampuan individu yang bersenyawa dalam masyarakat dan membangun keberdayaan masyarakat yang bersangkutan. Suatu masyarakat yang sebagian besar anggotanya sehat fisik dan mental, terdidik kuat, dan inovatif tentunya memiliki keberdayaan yang tinggi. Keberdayaan masyarakat adalah unsur-unsur yang memungkinkan suatu masyarakat bertahan dan dalam pengertian yang dinamis mengembangkan diri dan mencapai tujuan. Sedangkan memberdayakan masyarakat adalah upaya meningkatkan harkat dan martabat masyarakat yang tidak mampu untuk melepaskan diri dari perangkap kemiskinan dan keterbelakangan. Dengan kata lain, memberdayakan masyarakat adalah memampukan dan memandirikan masyarakat. 


\section{Tingkat Pengolahan Pekarangan}

Dalam pengelolaan lahan pekarangan yang merupakan kebun percontohan dalam rangka menanamkan tumbuhan sayuran yang merupakan dapur hidup bagi masyarakatnya. Untuk itu maka teori yang merupakan dasar dari kajian ini adalah pemberdayaan masyarakat merupakan upaya dimana masyarakat berdaya dan mandiri dalam mengelola berbagai potensi yang mereka miliki dalam mencapai kesejahteraannya.

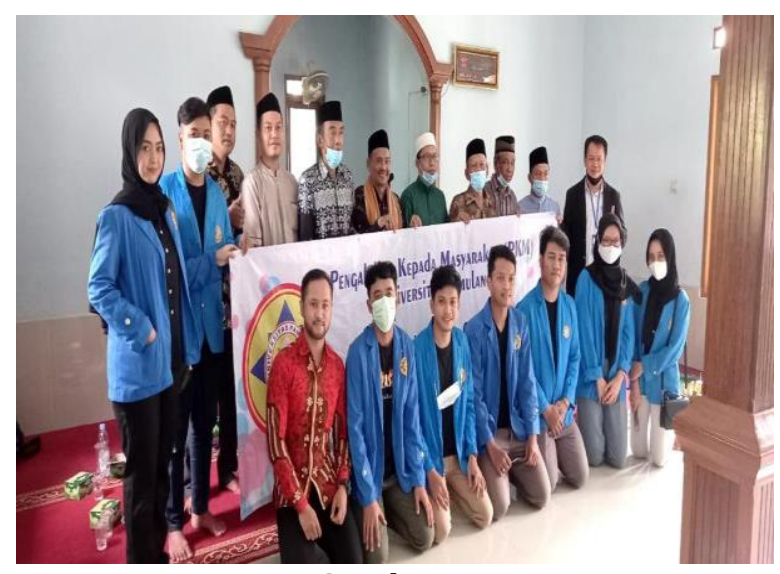

\section{KESIMPULAN}

Gambar.4

Pelaksanaan program pemberdayaan masyarakat merupakan suatu usaha yang dilakukan oleh pemerintah desa dalam rangka peningkatan kesejahteraan hidup masyarakatnya terutama dibidang ekonomi. Untuk itu dalam pelaksanaan program pemberdayaan masyarakat harus direncanakan secara bersama antara pemerintah desa dengan masyarakat dalam menentukan skala prioritas kebutuhan yang ada di dalam kehidupan masyarakat terutama yang berkaitan dengan kebutuhan ekonomi masyarakat desa.

Masih perlu upaya peningkatan dalam beberapa hal antara lain 1) pembinaan kelompok usaha ekonomi masyarakat agar lebih berusaha secara baik dalam rangka menyejahterakan kehidupan masyarakat; 2) ketrampilan menjahit bagi masyarakat agar mereka dapat memanfaatkan ketrampilan yang dimiliki dalam rangka pemenuhan kebutuhan dalam kehidupan keluarga oleh masyarakat yang bersangkutan; 3) penyuluhan kepada masyarakat untuk memelihara ternak secara profesional dalam rangka pemenuhan kebutuhan masyarakat; 4) pemanfaatan teknologi tepat guna oleh masyarakat dalam rangka menunjang aktivitas dalam kehidupan masyarakat seperti hand tractor yang dimanfaatkan untuk membajak sawah masyarakat; dan 5) pengolahan pekarangan masyarakat sebagai dapur hidup bagi masyarakat dalam rangka pemenuhan kebutuhan hidup masyarakat.

\section{UCAPAN TERIMAKASIH}

Terimakasih kami ucapkan kepada Kepala Desa Cidokom Bapak Sain Saputra, S.E., beserta jajarannya, Bang Zaenal dan Bapak Sugeng sebagai pengurus, para remaja dan masyarakat Desa Cidokom.

\section{DAFTAR PUSTAKA}

Ajimat, A., et al. (2020). Berwirausaha Memanfaatkan Media Sosial Pada Daerah Sepatan. ADI Pengabdian Kepada Masyarakat, 1(1), 69-76.

Bintari, W. C., et al.. (2019). Pelatihan Penyusunan Laporan Keuangan Secara Sederhana Pada Mahasiswa Fakultas Ekonomi Universitas Muhammadiyah Sorong. Abdimas: Papua Journal of Community Service, 1(2), 6-13.

Dewanti, R. N., et al. (2021). Penyuluhan Dan Pelatihan Keterampilan Sablon Pigment Pasta Manual Di Karang Taruna 03 Desa Cisauk. Jurnal PADMA: Pengabdian Dharma Masyarakat, $1(1)$. 
Eka, P. D., et al. (2020). Pengelolaan Keuangan Ponpes Dalam Rangka Peningkatan Masyarakat Mandiri Di Panti Asuhan Ikhwaniyah Cinta Yatim Dan Dhuafa. Jurnal Pengabdian Dharma Laksana, 3(1), 35-40.

Erlangga, H., et al. (2020). Pengembangan Kapasitas Usaha Kecil Kerupuk Kentang Di Kampung Ciawitali Desa Warnasari Kecamatan Pangalengan Kabupaten Bandung. Jurnal Pengabdian Tri Bhakti, 102-109.

Nurhayati, et al (2018). Pelatihan Pembukuan Di UKM Sumpia Chantika Dewi Cimindi Cimahi. Laporan Program Kepakaran Fisip Unpas Pengabdian Kepada Masyarakat Tahun Akademik 2016/2017, 1-22.

Paeno, P., et al. (2020). Pemanfaatan Sampah Plastik Untuk Kerajinan Rumah Tangga Taman Belajar Kreatif Mekar Sari. BAKTIMAS: Jurnal Pengabdian pada Masyarakat, 2(1), 57-61.

Putra, IGS., et al, (2020). Dampak Pelatihan Manajemen Kreatif Industri Peci Menuju Sentra Peci Di Desa Langonsari Kecamatan Pameungpeuk Kabupaten Bandung. Coopetition:Jurnal Ilmiah Manajemen. 11(1)

Rawi, R. D. P., \& Aprilia, L. (2019). Mekanisme Pendistribusian Produk Telkomsel Kepada Konsumen Melalui PT Telesindo Shop Di Kota Sorong.

Sunarsi, D. (2018). Analisis Motivasi Kerja Tenaga Pendidik Sukarela Pada Pusat Kegiatan Belajar Masyarakat (PKBM) Bimasda Kota Tangerang Selatan. Kreatif: Jurnal Ilmiah Prodi Manajemen Universitas Pamulang, 6(2), 53-65.

Suwanto, S., et al. (2020). Menggali Potensi, Memotivasi Dan Mengarahkan Generasi Muda Menyongsong Dunia Kerja Pada PKBM Cipta Tunas Karya Cipondoh Kota Tangerang. Jurnal Pengabdian Dharma Laksana, 2(2), 132-136. 